\title{
Verspreiding van persoonlikheidstipes by predikante in die gereformeerde Kerke van Suid-Afrika - om risikogroepe vir diensverlating te identifiseer
}

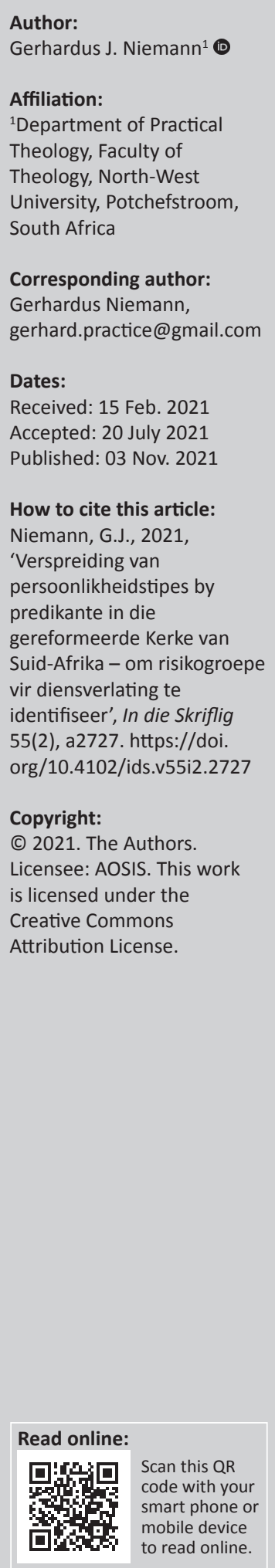

Distribution of personality types among ministers in the Reformed Churches of South Africa - to identify groups at risk for leaving service. With the use of a personality assessment based on the Hippocratic personality module, the researcher established that there is a significant distribution of personality types among pastors in the Reformed Churches in South Africa (RCSA). The main focus was to establish whether high-risk groups groups, which may be predisposed to leave the ministry prematurely, exist. This study revealed significant results in a group of pastors posing as possibly at risk for leaving the ministry, as well as a group of pastors that will function optimally within the RCSA. To establish this risk factor, the concept of 'goodness of fit' was used. In this way, the information gathered was used to develop a norm group, making it possible to effectively compare the individual pastor's personality within the larger scope of pastors in the RCSA. With the use of this norm group, the researcher was able to make conclusions that are specifically applicable to the pastors in the RCSA. It was established that the Phlegmatic personality type has the largest representation among ministers in the RCSA. This is significant due to the fact that ministers with this personality type are largely drawn to the ministry in the RCSA. On the other side of the spectrum, the Sanguine and Melancholic personality types have the lowest representations. This may represent a possible higher risk group for leaving the ministry.

Contribution: The research presented in this artcle, therefore, focused on the degree to which some pastors in the RCSA's personal tendencies influence their ministerial work and the likelihood of leaving the ministry.

Keywords: personality types; Reformed Churches; leaving service; ministerial work; equipment.

\section{Inleiding}

Volgens Rowell (2010:1) en Niemann (2010:140) verlaat'n groot aantal predikante die bediening. Veral vanweë faktore soos stres, moedeloosheid, hoë eise wat die bediening stel, skuldgevoelens, negatiewe denke, uitbranding, verlies aan passie en werkvreugde, interpersoonlike konflik, innerlike konflik asook eensaamheid en isolasie (Grobbelaar 2007:113). Hierdie faktore is eienskappe wat direk aan die domein van persoonlikheid verbind kan word (Meyer, Moore \& Viljoen 2003:4). Hier is vasgestel dat die persoon van die predikant - wie hy of sy is - 'n integrale rol in elke aspek van sy of haar dienswerk en lewe speel. God roep persone met verskillende persoonlikheidstipes tot sy diens en rus hulle daarvoor toe. Om hierdie doel te bereik, word persoonlikheidsontleding as afdeling van die sielkunde deur die pastoraat in oënskou geneem.

Heitink (1984) formuleer bogenoemde soos volg:

Daarbij moet onderscheid gemaakt worden tussen zijn persoonlijke identiteit en zijn pastorale identiteit. Vooral twee vragen duiken in dit verband regelmatig op: Wie ben ik? Wat kom ik doen? Terecht dat er geen beroep is, waarbij persoonlijke existentie en ambt zozeer verweven zijn als bij een pastor het geval is. (p. 16)

Heitink (1984:16) se insig vestig die aandag op die noue verband tussen predikante se persoonlikheid en die praktiese uitvoering van hulle ampswerk. Dit impliseer duidelik dat predikante se persoonlikheidsamestelling direk in hulle ampswerk en lewe meewerk.

Persoonlikheid verhoog eerstens die besef dat God die mens geskape het met sekere eienskappe wat die mens se natuurlike neigings bepaal. Tweedens, die interaksie tussen die 
mens en sy of haar omgewing beïnvloed die vertoning van persoonlikheidseienskappe. Derdens, die innerlike sterk en swak punte van persoonlikheidstipes bepaal en beïnvloed gedrag op verskillende wyses. Mense met verskillende persoonlikheidstipes sal verskillend op verskillende stresvolle omstandighede reageer. Persoonlikheid het veral 'n invloed op persone se beroepskeuse. Beroepskeuse, persoonlik benadering, die prediking, interpersoonlike verhoudings, gewoontes, motiveringsvlak, motiewe en selfs godsdiensbeoefening is alles eienskappe wat deur persoonlikheidstipe beïnvloed word. Diensverlating kan aktief teengewerk word indien predikante verstaan hoe hulle individuele persoonlikheidstipe hulle werk- en leefwêreld beïnvloed, veral die impak wat dit op hulle persoonlike lewens uitoefen.

Persoonlikheidstipes wat ' $n$ groter verteenwoordiging binne 'n gegewe beroep toon, het normaalweg ook 'n groter mate van werkstevredenheid. Volgens Louw en Edwards (2003:515) is bepaalde persoonlikheidstipes gewoonlik ook meer in pas met ' $n$ beroep. Die persoonlikheidstipes wat' $n$ lae verteenwoordiging binne 'n gegewe beroep het, loop ' $n$ groter risiko vir die ervaring van spanning. Persone wie se persoonlikheidstipes minder algemeen verteenwoordig word, toon ook 'n groter intensie om 'n gegewe beroep te verlaat, veral in vergelyking met diegene wie se persoonlikheidstipes 'n hoër verteenwoordiging in 'n gegewe beroep het.

Persoonlikheidstipes blyk 'n bepalende rol te speel by positiewe of negatiewe beroepservaring.

\section{Agtergrond}

Met hierdie navorsing word die persoonlikheidsmodel, ook bekend as temperamentsmodel, van Hippokrates (400v.C.) in die spesifieke konteks van predikante in die Gereformeerde Kerke in Suid Afrika (GKSA) toegepas. Alhoewel ander redes vir diensverlating oorweeg kan word, het die navorsing ten doel om die verspreiding van inherente persoonlikheidstipes by predikante in die GKSA vas te stel. Om hierdie doel te bereik, is empiriese navorsing onder predikante in die GKSA onderneem om hulle primêre persoonlikheidstipes met die gebruik van die Hippokratesmodel vas te stel. Die rede vir die gebruik van persoonlikheidsassessering is om moontlike groepe te identifiseer met die grootste risiko om die bediening te verlaat. Op hierdie wyse is die ingesamelde navorsingsresultate as 'n normgroep ontwikkel om individuele predikante doeltreffend met die groter groep te kan vergelyk (Terre Blanche, Durrheim \& Painter2010:494). Met die gebruik van die normgroep kon die navorser gevolgtrekkings maak wat spesifiek op die predikante in die GKSA as groep betrekking het. Die rede hiervoor is dat die predikante in die GKSA as 'n 'hoogs spesifieke ekosisteem' gesien kan word. Dit word so gesien omdat individue in die groep in 'n groot mate ooreenstem: beroep, werksomgewing, lewensomstandighede, kultuur, oortuigings, waardesisteem, opleiding, verwantskap, lewensen wêreldbeskouing, verantwoordelikheid, persepsies, godsdiens, ensovoorts (Becvar \& Becvar 2009:7).
Omdat die studie spesifiek op die predikante in die GKSA betrekking het, val die fokus op die mate waartoe predikante se persoonlikheid hulle dienswerk en gevolglik moontlike premature diensverlating beïnvloed.

Deur middel van kwantitatiewe navorsing het die navorsingsgroep 'n persoonlikheidassessering voltooi wat spesifiek op die vier persoonlikheidstipes volgens Hippokrates se teorie gebaseer is.

\section{Doelstellings}

Met hierdie benadering wil die navorser ' $n$ platform skep om predikante in die GKSA met 'n moontlike hoë risiko om die bediening vanweë hulle spesifieke persoonlikheidstipe te verlaat, af te rig. Hierdie afrigting sal selfkennis en verhoogde intra- en interpersoonlike bewusthede ten doel hê. Hogan (2014:1) meen dat persoonlikheidsontleding selfkennis en interpersoonlike vaardighede op 'n wetenskaplik gefundeerde wyse moontlik maak. Hy noem verder dat selfkennis mense in staat stel om hulle eie gedrag en die van ander te reguleer. Selfkennis dra tot 'n groot mate by tot ' $n$ individu se werksukses en werkstevredenheid (Berens \& Nardi 1999:3). Iemand met 'n gebrek aan hierdie vermoë vind dit moeilik om effektiewe inter- en intrapersoonlike verhoudings te handhaaf en kan om hierdie rede misluk, ongeag hoe intelligent of talentvol hulle ook al mag wees.

\section{Metode}

McAdams (2009:118) identifiseer vier basiese persoonlikheidstipes wat reeds omstreeks 400 v.C. by monde van Hippokrates omskryf is. Die basiese persoonlikheidstipes het elk ook, volgens Allen (2010:16), hulle eie sterk en swak punte. Hierdie persoonlikheidstipes is die volgende: die Sanguiniese; Choleriese; Melankoliese; en die Flegmatiese persoonlikheidstipe. Hippokrates het volgens Mischel, Shoda en Ayduk (2008:54) geglo dat daar vier basiese elemente is: grond, lug, vuur en water. Hy het hierdie vier basiese elemente met vier liggaamsvloeistowwe in verband gebring: Die eerste is bloed (warm bloed); die tweede 'choler' [geel gal]; diederde 'melancholy' [swart gal]; en die vierde 'phlegm'[flegma of slym]. Hippokrates het die vier persoonlikheidstipes so genoem omdat hy van mening was dat die vier verskillende liggaamsvloeistowwe die oorsaak van die vier verskillende persoonlikheidstipes is (Louw \& Edwards 2003:515). Vir Hippokrates het hierdie vier konsepte die volgende aangedui (sien Tabel 1).

Sowat 200 n.C. het 'n Griekse dokter, naamlik Van Galen, 'n gedetailleerde lys van die sterk en swak punte van die vier

TABEL 1: Hippokrates se klassieke persoonlikheidstipologie.

\begin{tabular}{llll}
\hline Element & Liggaamsvloeistof & Persoonlikheidstipe & Eienskappe \\
\hline Grond & Swart gal & Melancholies & Teruggetrokke, ongeduldig \\
Lug & Bloed & Sanguinies & Vrolik, uitgaande, kalm \\
Vuur & Geel gal & Choleries & Geïriteerd, knorrig, luidrugtig \\
Water & Flegma & Flegmaties & Stil, gelykmatig, onemosioneel \\
\hline \multicolumn{2}{l}{ Bron: Strelau, J., 1998, Temperament: A psychological perspective, p. 2, Plenum Press, }
\end{tabular}

Bron: Strelau, J., 1998, Temperament: A psychological perspective, p. 2, Plenum Press, London. 
persoonlikheidstipes saamgestel. Hierdie lys het deur die eeue behoue gebly en maak steeds deel uit van persoonlikheidsteoretisering. Met die ontwikkeling van die moderne wetenskap is die gedagte dat 'n persoon se persoonlikheidstipe deur liggaamsvloeistowwe bepaal word, verwerp, maar die viervoudige name om persoonlikheidstipes te klassifiseer, word steeds gebruik en aanvaar. Omdat Hippokrates se temperamentsmodel deur die loop van die jare met meertallige eienskappe uitgebrei is, word daar in hierdie studie eerder na 'n persoonlikheids model as temperamentsmodel verwys. Die skrywer klassifiseer Hippokrates se model as deel van die biologiese benaderings tot persoonlikheid. Carter (2007:64) wys daarop dat die klassifikasie help om die kompleksiteit van persoonlikheidsvariasies te vereenvoudig (sien Figuur 1 Figuur 5).

\section{Introversie-ekstroversie en emosioneel-onemosioneel as onderdele van persoonlikheidstipes}

Persoonlikheidstipes word, volgens Moerdyk (2012:135), in twee primêre dimensies verdeel, naamlik introversie en ekstroversie, asook emosionaliteit en onemosionaliteit. Carl
Jung (1875-1961) het 'n persoonlikheidsteorie ontwikkel wat bogenoemde dimensies as basis het (Jung 1971). Dit behels die konsepte van 'houdings' wat bestaan uit ekstroversie en introversie, asook 'funksies' wat uit emosionaliteit en onemosionaliteit bestaan. Die houdings en die funksies kombineer op verskillende wyses om op 'n sielkundige vlak persoonlikheidstipes te skep. Gewoonlik sal een houding en een funksie oorheers.

Kummerow en Quenk (2003:9) wys daarop dat Carl Jung introverte gesien het as persone wat meer in hulleself gekeer is. Introverte fokus op die innerlike wêreld of op subjektiewe sielkundige prosesse. Jung beskryf introversie ook as energie wat inwaarts verbruik word. Volgens Colman (2009:390) is introverte met hulle eie emosies en belewenisse gepreokkupeer en kan hulle dalk soms afsydig of selfs asosiaal voorkom. Introverte is, volgens Strelau (1998:6), meer gereserveerd en toon meer reflektiewe denkpatrone. Moerdyk (2012:135) wys weer dat ekstroverte hulleself, volgens Jung, tot die eksterne of objektiewe wêreld oriënteer. Ekstroverte het, volgens Colman (2009:270), baie sielkundige energie en openbaar 'n lewendige belangstelling en entoesiasme in die wêreld. Ekstroverte kom ook meer sosiaal as introverte voor. Jung beskryf ekstroversie as energie wat

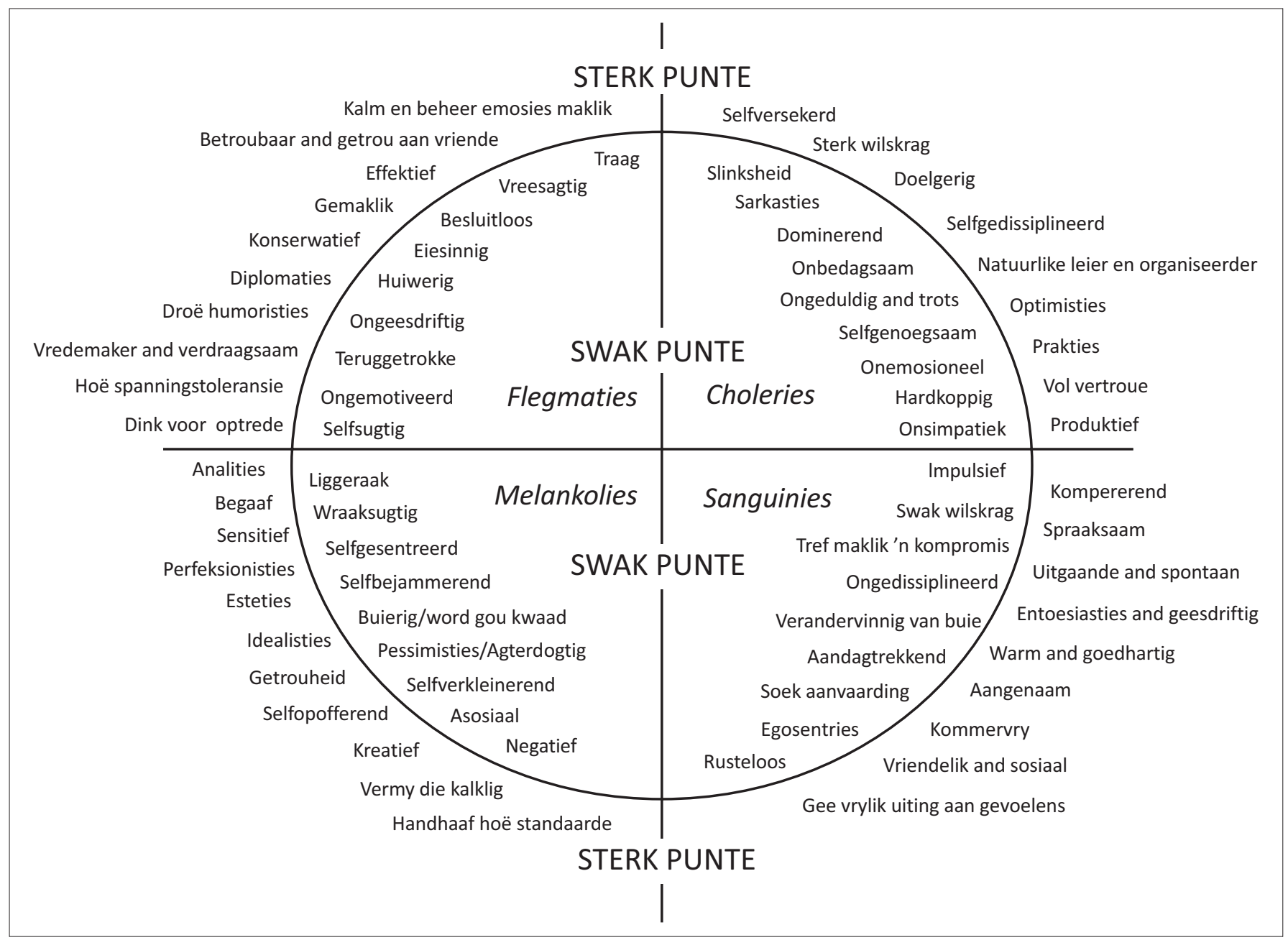

Bron: Burger, J.M., 2004, Personality, 6th edn., p. 249, Wadsworth, Belmont, CA

FIGUUR 1: Sterk en swak punte van Hippokrates se vier basiese persoonlikheidstipes. 


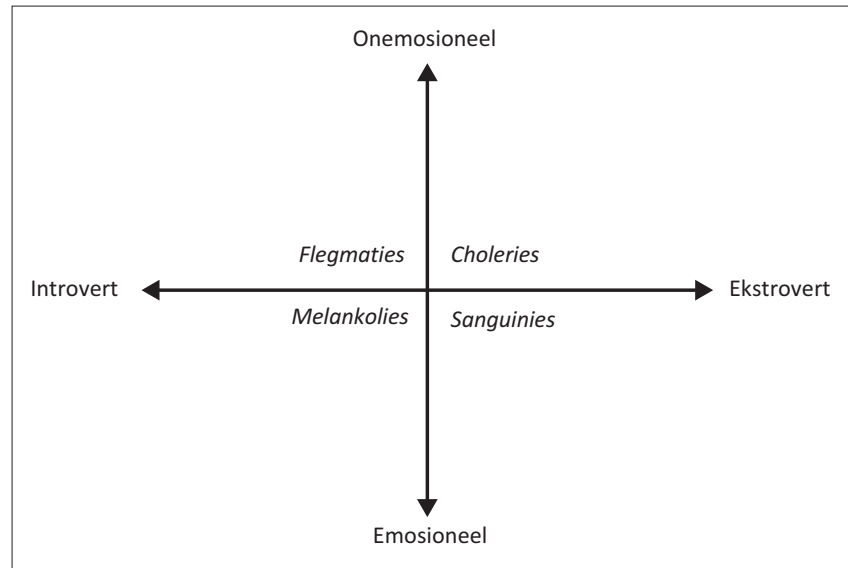

Bron: Burger, J.M., 2004, Personality, 6th edn., p. 249, Wadsworth, Belmont, CA; McAdams, D.P., 2009, The person: An introduction to the science of personality psychology, 5th edn., $p$ 118, Wiley, Hoboken, NJ.

FIGUUR 2: Die vier basiese persoonlikheidstipes wat deur die skale vir introversie-ekstroversie en emosioneel-onemosioneel aangetoon word.

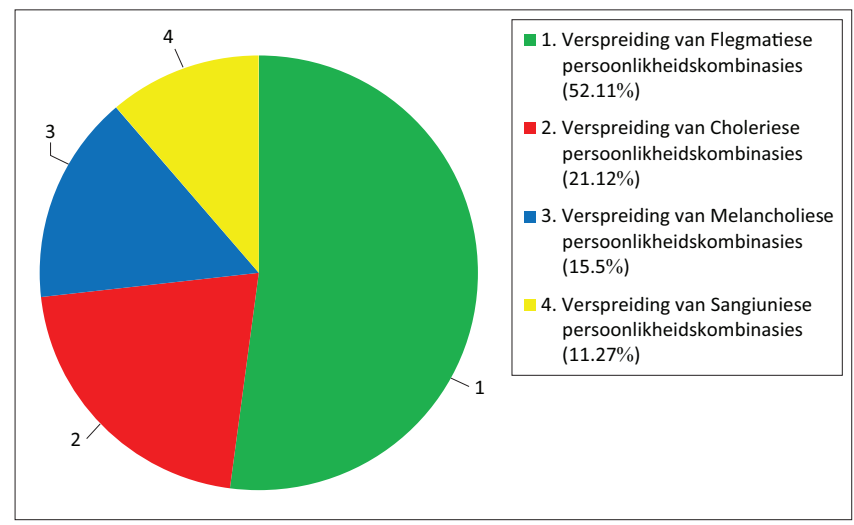

FIGUUR 3: Verspreiding van die vier persoonlikheidstipes onder predikante in die Gereformeerde Kerke in Suid Afrika.

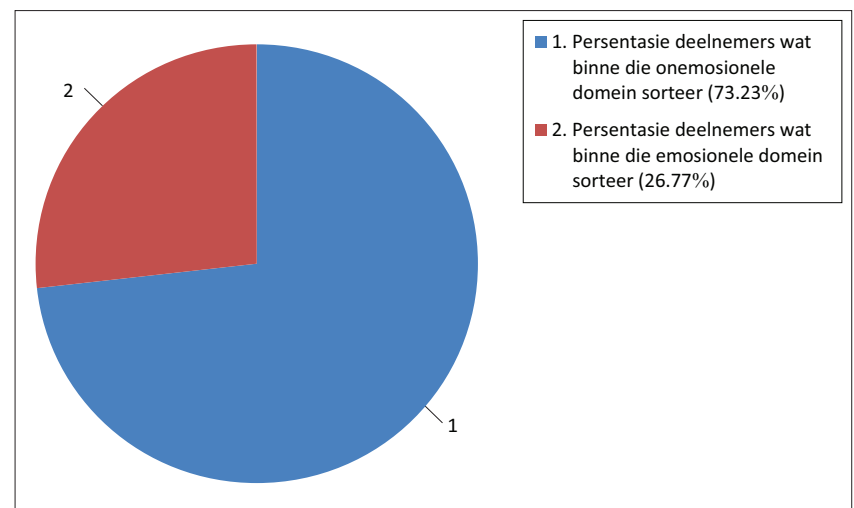

FIGUUR 4: Die verspreiding van respondente emosionele-onemosionele domein.

uitwaarts verbruik word en is dus 'n eksterne kognitiewe funksie. Hoewel introverte sowel as ekstroverte houdings in alle persone aanwesig is, is een daarvan gewoonlik bewustelik en dominant, terwyl die ander een onbewustelik en ondergeskik is.

Elke individu se persoonlikheidstipe kan, volgens Oswald en Kroeger (1999:29), dus op hierdie introvert-ekstrovertskaal aangedui word. Let wel: Niemand is uitsluitlik òf die een òf die ander nie; daar is graadverskille. Sommige

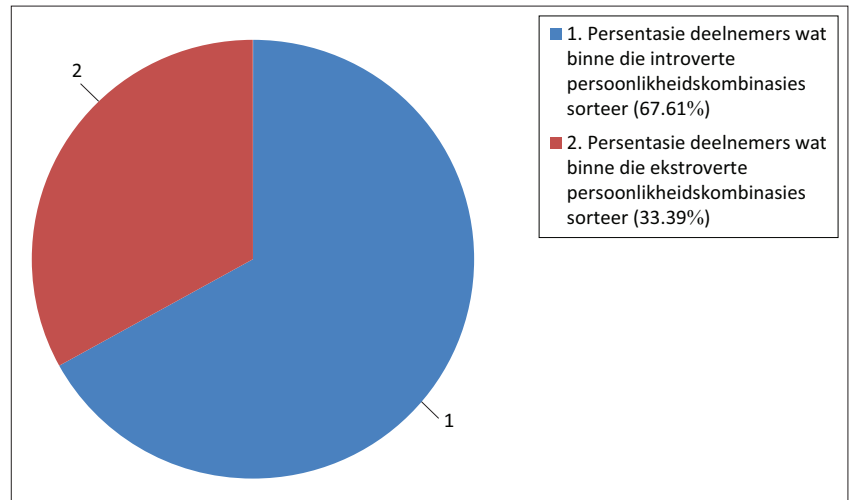

FIGUUR 5: Die verspreiding van respondente op die introversie-ekstroversie skaal.

introverte is byvoorbeeld meer introvert as ander en sommige ekstroverte is meer ekstrovert as ander. Volgens Bennett en Bennett (2005:20) probeer introverte om hulleself, ander en die wêreld waarin hulle leef op 'n intra-kognitiewe wyse te verstaan. Denke of idees word met mekaar in verband gebring ten einde algemene persepsies of oplossings vir 'n probleem te vind. Introversie is daarom vir Du Toit (2005:3) 'n evaluerende funksie. Dit gaan oor die aanvaarding of verwerping van idees op grond van aangename of onaangename gevoelens wat die idee wek.

Elke persoon se persoonlikheidstipe kan dus ook op die emosioneel-onemosioneel-skaal skaal aangedui word. Uiters emosionele persone sal, volgens Larsen en Buss (2010:76), byvoorbeeld 'n groot mate van emosionele skommeling ervaar. Hierdie mense se gedrag word sterk deur hulle gemoedstoestand beïnvloed. Aan die ander kant van die skaal is uiters onemosionele mense wat, volgens McAdams (2009:118), diegene is wat feitlik geen emosionele skommeling ervaar nie. Hierdie persone raak nie dikwels ontsteld of terneergedruk nie, maar terselfdertyd raak hulle ook nie dikwels opgewonde nie. Weer is niemand óf die een óf die ander nie; ook hier is graadverskille. Volgens Feist en Feist (2009:259) is sommige mense meer emosioneel en ander weer meer onemosioneel. Wanneer 'n diagram van hierdie faktore geteken word, kry ons vier kwadrante wat die vier basiese persoonlikheidstipes aandui.

Ekstroversie en introversie beteken, volgens Jung (1971), nie bloot 'uitgaande' of 'skaam' nie. Baie introverte is nie skaam nie; hulle verkies net om hulle tyd rustig in 'n bekende omgewing deur te bring. Die twee ekstroverse persoonlikheidstipes is die Choleriese en Sanguiniese. Beide is geneig om gou tot aksie oor te gaan en druk hulle emosies en gedagtes druk hulle emosies en gedagtes uit. uit. Hierdie persoonlikheidstipes is ook albei konstant bewus van en reageer op dit wat buite hulleself gebeur. Volgens Cavanaugh en Blanchard-Fields (2011:327) is ekstroverte ook geneig om meer te praat as wat hulle luister. Volgens Papalia, Wendkos Olds en Dukskin Feldman (2008:403) gebruik ekstroverte meer handgebare en gesigsuitdrukkings as introverte. Ekstroverte is ook geneig om te herhaal of om dinge te oorbeklemtoon. Iemand 
met 'n ekstroverse persoonlikheid gebruik ander as 'n klankbord in hulle denkproses. 'n Mens kan sê dat ekstroverte hardop dink deur met ander te praat.

Aan die ander kant sal die introverse persoonlikheidstipes, die melancholiese en flegmatiese meer met idees of gebeure gekonfronteer word. Volgens McAdams (2009:118) kan hulle dalk tyd nodig hê hulle tyd neem om nuwe inligting te verwerk voor hulle reageer. Waar ekstroverte nuwe inligting verwerk deur daaroor te praat, sal introverte tyd benodig vir refleksie om die nuwe inligting te internaliseer en te assimileer. Introverte sal probeer om alles vooruit te beplan. Hulle sal situasies probeer vermy waar hulle moet optree sonder deeglike refleksie en beplanning. Introverte kan in die kalklig wees en kan goed in uitgaande beroepe funksioneer, maar hulle sal, volgens Cavanaugh en Blanchard-Fields (2011:319), meer emosionele energie as ekstroverte verbruik. Die onderskeid tussen introverte en ekstroverte hang nie af of hulle skaam of uitgaande is nie, maar eerder of hulle hul denke internaliseer of uitwaarts uitdruk. Bogenoemde uiteensetting bevestig die feit dat die vier basiese persoonlikheidstipes verskeidenheid en betekenis aan die mensdom gee. Dit onderstreep die feit dat elke persoon 'n individu is.

\section{Persoonlikheidstipes is 'n Godgegewe kwaliteit}

Volgens Sewell (2008:39) is 'n mens se persoonlikheid ingebore, en daarom 'n Godgegewe kwaliteit. Psalm 139:416 getuig van God se inherente skeppingswerk van die mens. God het om hierdie rede aan elke mens, volgens OswaldenKroeger(1999:33), bepaaldepersoonlikheidstrekke gegee wat elkeen uniek maak (Gen 1:27). Natuurlik kan persone bepaalde aspekte van hulle gedrag aanpas, maar elkeen se inherente persoonlikheid bly teenwoordig en bepaal hoe 'n mens lewenslank optree. Deur die werking van die Heilige Gees vernuwe God daardie aspekte van die mens se persoonlikheid om die gelowige te omskep in die persoon wat God hom of haar oorspronklik bedoel het om te wees (Burke 2013:24). Dit is 'n aanduiding van God se inherente betrokkenheid by elkeen se persoonlikheid.

\section{Empiriese ondersoek \\ Proses van data-insameling en analise}

Ten einde empiriese navorsing onder predikante in die GKSA te onderneem, is 'n steekproef gedoen om die verspreiding van predikante se primêre persoonlikheidstipes vas te stel. In 'n poging om ' $n$ verteenwoordigende steekproef te verkry, is al die diensdoenende predikante in die GKSA tydens die navorsing betrek. Op hierdie wyse is alle bevooroordeling ten opsigte van wie by die navorsing betrek word, uitgeskakel, en is al die predikante ' $n$ gelyke kans gegun om ' $n$ bydrae tot die navorsing te lewer.

Die predikante van die GKSA is uitgenooi om die persoonlikheidsvraelys vrywillig en anoniem te voltooi. Dit is ' $n$ selfrapporteringsvraelys is 'n selfrapporteringsvraelys wat deur Joubert (2005) gestandaardiseer is om die vier primêre persoonlikheidstipes van Hippokrates vas te stel. Met hierdie standaardiseringsproses is die geldigheid en betroubaarheid van die vraelys bepaal. Om die vraelys te voltooi, was daar van die deelnemers verwag om 48 kort stellings persoonlik te beoordeel en telkens met 'ja', 'onseker' of 'nee', namate die respondente met die stellings ooreenstem, te antwoord. Die predikante is ingelig dat die vrae handel oor wyse waarop hulle dink, voel en optree en optree en dat hulle dienooreenkomstig antwoorde moet verstrek.

Omdat die predikante in die GKSA oor Suid-Afrika en Namibië verspreid is, het die navorser 'n elektroniese weergawe van die persoonlikheidsvraelys geskep. Hierdie elektroniese weergawe van die persoonlikheidsvraelys is aan al die diensdoenende predikante per e-pos via die Administratiewe Buro van die GKSA se e-poslys gestuur. 'n Moontlike totaal van 270 predikante het die vraelys ontvang (soos aangedui in die 2016-weergawe van die Almanak van die GKSA wat die statistiese kerkverbandinligting bevat). Uit hierdie navorsingspopulasie is ' $n$ totaal van 71 vraelyste terugontvang wat vir databerekening gebruik is. Die finale steekproef bestaan dus uit $26.3 \%$ van die totale predikantepopulasie in die GKSA.

Met die inagneming daarvan dat die predikante in die GKSA as navorsingsgroep gebruik is, moet daar vasgestel word of die predikante wat aan die navorsing deelgeneem het as 'n verteenwoordigende steekproef beskou kan word. Volgens Terre Blanche et al. (2010:236) is daar twee aspekte wat in oorweging hiervan tersaaklik is. Ten eerste moet die grootte van die steekproef in sy eie reg beoordeel word. Ten tweede moet die betekenisvolheid van die sosiale en kulturele veranderlikes ten opsigte van die navorsingspopulasie beoordeel word.

Wanneer Terre Blanche et al. (2010:236) se riglyne in verband met die steekproefgrootte in ag geneem word, kan dit wel as verteenwoordigend van die totale populasie beskou word. Wanneer die getal predikante wat aan die navorsing deelgeneem het in verhouding met die totale populasie gebring word, het meer as een uit elke vier diensdoenende predikante in die GKSA aan die steekproef deelgeneem. Wanneer die sosiale en kulturele veranderlikes in ag geneem word, word die steekproef as verteenwoordigend van die totale populasie beskou. Die homogene aard van die sosiale en kulturele faktore van die navorsingspopulasie dien as versterking van hierdie argument. Die groter studiepopulasie waaraan die persone in die steekproef behoort, deel dieselfde beroep, geloof, oortuigings, lewens- en wêreldbeskouing, kerkverband, opleiding, sosiale konteks, ensovoorts. Met die inagneming van die steekproefgrootte, asook asook die homogene aard van die studiepopulasie, kan die gevolgtrekking gemaak word dat die steekproef inderdaad as verteenwoordigend beskou kan word en dat die gevolgtrekkings wat uit die resultate voortvloei op die totale populasie betrekking sal hê. 


\section{Etiese oorwegings}

Met inagname van AOSIS se riglyne vir etiese navorsings is die volgende stappe gedoen om te verseker dat hierdie studie op ' $n$ etiese wyse gedoen is. Deelname aan die studie was anoniem. Elke respondent se resultate kon om die rede ook totaal vertroulik hanteer word. Die respondente is nie gevra om enige persoonlike inligting weer te gee nie. Voor die aanname van dié rede navorsing is respondente meegedeel dat elkeen se deelname aan die studie totaal vrywillig is. Geen respondent was onder enige verpligting om aan die studie deel te neem nie. Vooraf is die respondente ingelig is die respondente ingelig waaroor die studie handel. 'n Kort beskrywing van die doelstellings is aan die respondente gegee. Goedkeuring vir die studie is by die NoordwesUniversiteit se etiese komitee verkry.

\section{Navorsingresultate}

\section{Verspreiding van die vier primêre persoonlikheidstipes onder predikante in die Gereformeerde Kerke in Suid-Afrika}

Met 'n deursnee-analise oor die verspreiding van persoonlikheidstipes binne die studiepopulasie is die volgende resultate verkry:

Dit blyk dat die meeste $(52.11 \%)$ respondente binne die Flegmatiese persoonlikheidstipe (kategorie vir die onemosionele introverte) sorteer. Die tweede meeste respondente $(21.12 \%)$ sorteer binne die Choleriese persoonlikheidskombinasies (kategorie vir die onemosionele ekstroverte). Wat die verspreiding van die Melancholiese persoonlikheidskombinasies betref, sorteer 15.5\% van die respondente binne hierdie introvert-emosionele kategorie. Die minderheid van slegs $11.28 \%$ sorteer binne die Sanguiniese persoonlikheidskombinasies (ekstroverteemosionele kategorie).

In geheel beoordeel is dit merkwaardig dat die meeste respondente na die Flegmatiese as primêre persoonlikheidstipe neig. Dit is belangrik om daarop te let dat Die Sanguiniese persoonlikheidstipe, wat die laagste in die studiepopulasie verteenwoordig word, is die direk teenoorgestelde van die Flegmatiese persoonlikheidstipe. Hierdie lae verteenwoordiging van die Sanguiniese persoonlikheidstipe onder predikante in die GKSA dien as bevestiging dat die predikante wat aan die studie deelgeneem het grotendeels na die onemosionele introverse eerder as emosioneel ekstroverse persoonlikheidstipes neig.

Met verdere analise van die ingesamelde data kan die verspreiding van introversie-ekstroversie, asook emosionaliteitonemosionaliteit in die domein ook besonder insiggewend wees:

Bogenoemde bring mee dat die oorgrote meerderheid (73.23\%) van die predikante primêr na die onemosionele domein neig. Dit bring mee dat slegs $26.77 \%$ van die predikante na die emosionele persoonlikheidstipes neig.
Dit is merkwaardig omdat die oorweldigende groepering van predikante onemosionele eienskappe vertoon. Onemosionele persoonlikheidtipe word tipies gekenmerk deur eienskappe soos kalmte, beheerste emosies, getrouheid, gemaklikheid, effektiwiteit, konserwatiwiteit, diplomasie, hoë spanningstoleransie en selfstandigheid. Verder toon onemosionele persoonlikheidstipes eienskappe soos besluitloosheid, eiesinnigheid, traagheid en teruggetrokkenheid. Dit kan moontlik wees dat die werksomgewing van Gereformeerde predikante onemosionele eienskappe vereis.

Met verdere analise van die verspreiding van predikante op die introversie-ekstroversie-skaal, sorteer $67.61 \%$ van die deelnemers onder die introverse persoonlikheidstipes, terwyl $33.39 \%$ in die ekstroverse tipes val.

Indien daar aanvaar kan word dat hierdie persoonlikheidstipes binne die algemene populasie meer eweredig verspreid is, blyk dit dat die blyk dit dat die $52.11 \%$ onemosionele introverte merkwaardig is. Dit is 'n aanduiding dat hierdie spesifieke persoonlikheidstipes meer tot die bediening in die GKSA aangetrokke is. Dié geneighdheid geneigdheid is veral betekenisvol indien dit gesien word in kontras met die verteenwoordiging van predikante in die domein van emosionele ekstroverte wat slegs $11.27 \%$ is. Die vraag wat hieruit voortvloei, is die volgende: Waarom blyk daar onder die predikante in die GKSA 'n geneigdheid na die onemosioneel introverse persoonlikheidskombinasies persoonlikheidskombinasies bestaan? Hierdie persone is, volgens Jung (1971), baie intellektueel gefokus en toon min gevoel vir die alledaagse lewe. Die tipe sluit asketies filosofiese persone in wat baie onprakties, sosiaal geïnhibeer, baie privaat en geslote voorkom. Om hierdie rede vorm predikante wat tot emosionele ekstroversie geneig is ' $n$ risikogroep wat die bediening straks kan verlaat.

\section{Rede vir die verspreiding van persoonlikheidstipes by predikante in die Gereformeerde Kerke in Suid Afrika}

Hierdie verspreiding van predikante is veral betekenisvol wanneer daar na individuele voorkeure gekyk word. Owens (2015:22) toon aan dat daar 'n sterk korrelasie tussen persoonlikheidstipe en beroep bestaan. Volgens Onoyase en Onoyase (2009:109) is dit belangrik om daarop te let dat sekere persoonlikheidstipes sekere beroepe meer geskik of gunstig sal vind as ander. Natuurlik word daar nie net een persoonlikheidstipe binne ' $n$ bepaalde beroep gevind nie, maar is daar gewoonlik 'n groter verteenwoordiging van een persoonlikheidstipe as die ander. Volgens Briggs-Myers et al. (2003:286), wat ook met persoonlikheidstipes werk, kan verskillende persoonlikheidstipes dieselfde werk verrig, maar sal hulle verskillende benaderings volg om dit uit te voer - die een moontlik meer effektief as die ander. Dit kom juis na vore in die uitvoer van beroepsrolle waar daar spanning kan ontstaan. Indien daar, volgens Lounsbury et al. 
(2008:2), 'n groot verteenwoordiging van 'n bepaalde persoonlikheidstipe in verhouding met ander in 'n gegewe beroep voorkom, mag nuwe benaderings en innovasies vanweë 'groepdenke' laag wees.

Volgens Kristof-Brown, Zimmerman en Johnson (2005:281) blyk daar ook 'n verband te bestaan tussen die soort werksaktiwiteite wat persone vervullend vind en die tipe werksomgewing wat persone verkies. In hierdie verband blyk dit dat predikante met die introverte-onemosionele persoonlikheidstipe meer persoonlike werksbevrediging en -sukses in die werksomgewing wat die GKSA bied, sal beleef. Daar kan aanvaar word dat die teenoorgestelde vir die ekstroverte-emosionele persoonlikheidstipe sal geld. Dus kan hierdie persoonlikheidstipe as 'n risikogroep gesien word om die bediening te verlaat omdat die werksomgewing baie emosionele energie van hulle sal vereis.

Owens (2015:2) wys op die belangrikheid daarvan om die impak van verskillende werksomgewings op verskillende persoonlikheidstipes te verreken. Daar bestaan dus voor- en afkeure op die introversie-ekstroversie en emosioneelonemosioneel skale binne die werksomgewing. Om hierdie rede sal verskillende persoonlikheidstipes met hulle inherente voor- en afkeure met die tipe aktiwiteite sowel as die tipe omgewing wat hulle as stimulerend of bevredigend vind, assosieer. Hierdie uitgangspunt staan bekend as die 'persoon-omgewing-geskiktheid'-teorie.

Volgens Nikolaou (2003:639) blyk pasgraad komplementerend sowel as aanvullend te wees. Komplimenterende pasgraad vind plaas wanneer die persoon soortgelyke eienskappe besit as ander individue in die werksomgewing. Aanvullende pasgraad ontstaan wanneer 'n persoon eienskappe of vermoëns in die werksomgewing inbring wat instrumenteel bydra tot die bestaande eienskappe wat die werksomgewing kenmerk. Pasgraad vind in ieder geval wanneer daar 'n dinamiese interaksie tussen die persoon en die omgewing is.

Daarom bestaan daar verskillende eienskappe wat verskillende persoonlikheidstipes belangrik vind in 'n ideale werksomgewing. Vriendelike en ondersteunende medewerkers blyk belangrik vir die ekstroverte-emosionele persoonlikheidstipe te wees. Dit is die persoonlikheidstipe wat die laagste verteenwoordiging onder predikante in die GKSA het. Hulle verkies om op die eksterne wêreld van mense en gevoelens te fokus. Hierdie werksomgewing is weer minder belangrik vir die introverte-onemosionele persoonlikheidstipe wat die hoogste verteenwoordiging in die GKSA het. Hulle verkies onafhanklikheid en selfstandigheid in hulle werksomgewing. As deel van hulle ideale werksomgewing is hulle meer op die teoretiese aspekte van hulle werk gefokus as op emosionele verhoudings met mense.

Die verspreiding van persoonlikheidstipes kan, volgens Owens (2015:3), binne bepaalde beroepe met bepaalde eienskappe van die werksomgewing in verband gebring word. Sekere beroepe sal, volgens Onoyase en Onoyase (2009:114), sekere gedrag beloon en spesifieke gedrag vereis. Persone wat in pas is met bepaalde beroepe sal ook in ooreenstemming met die rolvereistes van die beroep optree. Om hierdie rede sal persone met sekere persoonlikheidstipes tot bepaalde beroepe aangetrokke wees en nie tot ander nie. Volgens Briggs-Myers et al. (2003:300) is diversiteit egter binne 'n beroep nodig om stagnasie en 'groepdenke' te verhoed. Wanneer daar 'n groot meerderheid van een persoonlikheidstipe in ' $n$ beroep is, sal 'n bepaalde wyse van gedrag, denke en optrede oorheersend wees en as die norm aanvaar word.

\section{Redes vir diensverlating by predikante}

As gevolg van individuele voorkeure is dit belangrik om sensitief te wees vir faktore wat dalk spanning in predikante se beroepslewe mag veroorsaak. Predikante wat spanning beleef, mag hulleself in ' $n$ werksomgewing bevind wat nie noodwendig met hulle natuurlike voorkeure ooreenstem nie. Dit mag wees dat hierdie predikante vanweë verskeie redes nie hulle omgewing kan verander nie (bv. die keuse om na 'n meer gepaste gemeente te verskuif, lê nie in die mag van die predikant self nie, maar by eksterne faktore waaroor hulle nie beheer het nie), en met hierdie spanning moet die predikant voortleef of die diens verlaat. In hierdie opsig mag predikante voel dat hulle te veel tyd aan opleiding bestee het om ' $n$ ander beroep buite die kerk na te volg, of dat die risiko vir die verlies van inkomste te groot sal wees indien hulle 'n nuwe werksomgewing betree.

Die Sanguiniese persoonlikheidstipe is as risikogroep vir die belewing van lae lewensukses en -tevredenheid sowel as depressie geïdentifiseer. Weens die emosionele aard van die Sanguiniese persoonlikheidstipe mag hierdie persone meer deur stresfaktore in die bediening geaffekteer word.

Persoonlikheidseienskappe soos moedeloosheid, oorsensitiwiteit, verpersoonliking van kritiek, voortdurende skuldgevoelens en negatiewe denke beïnvloed hulle ervaring van stres in die bediening. Met die in ag genome stresfaktore onder predikante in die GKSA, blyk die Sanguiniese persoonlikheidstipes besonder kwesbaar vir die ervaring van spanning en moontlike diensverlating te wees.

Faulkner $(2001: 7,8)$ gee verdere redes waarom predikante die bediening verlaat. Hy verwys na die sogenaamde Prisoners of War (POW)-sindroom. Volgens hierdie sindroom sien predikante hulleself as 'prisoners of war'. Hulle voel, met ander woorde, vasgevang in hulle omstandighede. Hulle opleiding voel soos vermorste tyd en energie. Soos krygsgevangenes voel hulle hulpeloos om aantygings teen hulle te beveg. Hulle voel geboei teen die muur van ontevredenheid en voel beroof van liefde, aanvaarding en om self bedien te word. Niemann (2010:4) wys verder daarop dat 
hierdie predikante moontlik mishandel kan voel deur hulle belewenis dat sommige gemeentelede hulle bedieningswerk minag. Dit is in besonder van toepassing op die emosioneel ekstroverse persoon wat hulle gevoelens 'op hulle mou dra'.

Dit laat die persoon in hierdie geval met twee keuses: Hulle sal of hulle werksomgewing by hulle persoonlikheidstipe moet aanpas óf hulle sal by hulle werkvereistes moet aanpas. Dit mag wees dat persone in hierdie omstandighede albei oplossings gedeeltelik sal moet toepas. Die ideaal sal wees dat predikante, sonder om die bediening te verlaat, ' $n$ omgewing sal vind of skep wat meer met sy persoonlikheidstipe sooreenstem. Vir predikante in die GKSA is dit vanweë die beroepstelsel of die gemeenteprofiel self nie altyd moontlik om so verandering te maak nie en is aanpassing of diensverlating die enigste uiteindelike opsies.

Lounsbury et al. (2008:4) maak melding daarvan dat persone wat 'n spesifieke beroep verkies gewoonlik om dit in ooreenstemming met hulle persoonlikheidstipe te doen. Dit kan dus veronderstel word dat mense se persoonlikheidstipe hulle beroep vorm en nie die beroep wat die persoonlikheid vorm nie. In hierdie opsig word predikante nie Flegmaties of Choleries nadat hulle die beroep betree nie, maar betree eerder die beroep as gevolg van hulle persoonlike voorkeure. Om hierdie rede deel persone in dieselfde beroep grootliks soortgelyke persoonlikheidseienskappe. In hierdie opsig blyk die Flegmatiese persoonlikheidstipe die 'model' persoonlikheidstipe by predikante in die GKSA te wees. Die Sanguiniese persoonlikheidstipe wat by verre in die minderheid is, sal moontlik in konflik wees met die stereotipiese gedrag van predikante met die Flegmatiese persoonlikheidstipe. Soos reeds genoem, is hierdie twee persoonlikheidstipes direkte teenoorgesteldes van mekaar. Predikante met die Sanguiniese persoonlikheidstipe mag om hierdie rede meer spanning, angs en konflik beleef omdat hulle gedrag, denke en werkswyse nie by die 'norm' pas nie.

\section{Verspreiding van persoonlikheidstipes en beroepsbelewenis}

Die aandag word hier spesifiek toegespits op die effek wat die verspreiding van persoonlikheidstipes onder predikante in die GKSA op beroepservaring het. Stone (2009:16) noem in hierdie verband dat die waarneming van die groter groep se eienskappe ook dié van die individu weergee. Hier word op die verteenwoordiging van persoonlikheidstipes by predikante binne die GKSA gefokus. Sodoende kan bepaal word watter persoonlikheidstipes 'n groter risiko loop vir negatiewe beroepservaring en gevolglik diensverlating.

Om vas te stel of bepaalde persoonlikheidstipes tot 'n gegewe beroep aangetrokke is of nie kan help om risikogroepe te identifiseer. Navorsing wat oorspronklik deur Holland (1996:397) gedoen is, hetvasgestel dat diepersoonlikheidstipes wat 'n lae verteenwoordiging binne 'n gegewe beroep het, 'n groter risiko vir die ervaring van sielkundige spanning het.
Die rede vir die belewing van sielkundige spanning is gegrond op die mate waartoe persoonlikheidstipes in pas met hulle werksomgewing is. Volgens Chess en Thomas (1996:189) is daar 'n besondere verhouding tussen 'n persoonlikheidstipe, pasgraad en beroepservaring.

Volgens Burger (2004:267) moet daar dus 'n kritiese vraag in verband met persoonlikheidstipes beantwoord word: 'Watter tipe omgewing is die meeste van pas vir persone met verskillende persoonlikheidstipes?' Louw en Louw (2007:125) verwys in verband met persoonlikheidstipes na die konsep 'pasgraad'(goodness of fit/poorness of fit) wat verwys na die gevolge van die interaksie tussen persone se persoonlikheidstipes en die omgewing waarin hulle hulself bevind. Volgens hierdie model, sal optimale funksionering (bv. positiwiteit, optimisme, kreatiwiteit, goeie menseverhoudinge, goeie selfbeeld, ens.) plaasvind indien persone se persoonlikheidstipe en die omgewing waarin hulle hulself bevind in pas is. Burger (2004:267) wys verder op die feit dat indien persone se persoonlikheidstipes en die omgewing waaraan hulle blootgestel word nie in ooreenstemming met mekaar is nie, kan probleme soos interpersoonlike konflik ontwikkel (Chess \& Thomas 1996:191). Volgens Larsen en Buss (2010:7) is persoonlikheid iets wat deel van 'n persoon vorm. Dit impliseer dat persoonlikheid iets is wat iemand van een situasie of omgewing tot die volgende dra.

Hierdie model wys, volgens Colman (2009:323), dat persone bepaalde lewenseise beter sal hanteer indien hulle in pas met hulle omgewing is. Dit verwys na na hulle vermoëns en eienskappe, asook hulle styl van gedrag binne 'n spesifieke konteks. Met ander woorde, nie almal wat in dieselfde omstandighede is, toon dieselfde reaksie nie. Wanneer take op so ' $n$ wyse aangebied word wat in pas met iemand se gedrag, belangstellings of persoonlike styl is, kan optimale funksionering plaasvind. Mense se interaksie met 'n spesifieke omgewing het 'n sterk invloed op hul gedrag. Wanneer hulle nie in pas is met hulle omgewing nie, sal hulle ook nie optimaal funksioneer nie.

Pasgraad sal ook persone se belewenis van selfwaarde beïnvloed. Om die rede wys Heller, Judge en Watson (2002:829) dat pasgraad 'n direkte invloed op werk- en lewenstevredenheid het. Persone wat swak funksioneer in 'n bepaalde omgewing blameer maklik hulleself. Dit het, met ander woorde, negatiewe selfevaluering tot gevolg. Hierdie negatiewe evaluasie word, volgens Engelbrecht in Maartens (2002:143), nog verder deur ander se kritiek versterk. Die persoon se klaarblyklike onbevoegdheid kan dus moontlik aan pasgraad toegeskryf word.

'n Onderliggende persoonlike geneigdheid beïnvloed, volgens Johns en Saks (2005:115), beroepservaring. Hierdie persoonlike geneigdheid sal, by wyse van 'n persoon se persoonlikheid, meer of minder werkstevredenheid ervaar ten spyte van konteks of die ervaring van regverdigheid. Persoonlikheidstipes wat ' $n$ groter verteenwoordiging binne 'n gegewe beroep het, ervaar normaalweg, volgens Owens (2015:22), ook 'n groter mate van werkstevredenheid omdat 
hierdie persoonlikheidstipes gewoonlik ook meer in pas met hulle gekose beroep is. Navorsing wat deur Kristof-Brown et al. (2005:285) gedoen is, het aangetoon dat diegene wat hulleself as positief beskou, gewoonlik ook die persoonlikheidtipe met ander in die beroep deel.

Omdat daar 'n geneigdheid onder predikante in die GKSA tot die Flegmatiese persoonlikheidstipe bestaan, blyk die rolvereistes van predikante in die GKSA ook in ooreenstemming te wees met die kenmerke van hierdie persoonlikheidstipe. Johns en Saks (2005:115) noem in hierdie verband dat sekere ingebore persoonlikheidseienskappe tot werkstevredenheid aanleiding gee. Dit is belangrik dat predikante in die GKSA nie noodwendig eksklusief volgens hierdie eienskappe gestereotipeer moet word nie. Al vier primêre persoonlikheidstipes word onder predikante in die GKSA verteenwoordig. Dit is bloot om aan te toon watter persoonlikheidseienskappe oor die algemeen van predikante in die beroep verlang word. Coetzee en Schreuder (2002:53) verwys na hierdie eienskappe as 'beroepsankers' omdat dit primêr van hulle rol as predikant verlang word.

Wanneer daar, volgens Kristof-Brown et al. (2005:282), 'n mispassing tussen persoonlikheidstipe en werksomgewing bestaan, voel hierdie persoon gewoonlik moeg en onbevoeg. Volgens hierdie teorie veroorsaak 'n mispassing dikwels uitbranding en gevoelens van onbevoegdheid omdat dit meer energie en inspanning verg om binne die teenoorgestelde pool van die voorkeurgedrag te funksioneer. 'n Mispassing tussen persoonlikheidstipe en beroep veroorsaak ook ontmoediging en depressie. Die rede hiervoor is dat 'n persoon, ten spyte van groter inspanning en moeite, die eindresultate steeds minder bevredigend vind as wat die geval sou gewees het met resultate wat deur voorkeurgedrag verkry word. Sulke take verg, volgens Erdogan en Bauer (2005:862), minder inspanning, en gee meer bevrediging en beter prestasie. Gevolglik sal die beroepservaring ook meer bevredigend wees. Pasgraad tussen persoonlikheidstipe en omgewing dien dus as mediator tot positiewe of negatiewe beroepservaring.

Studies in verband met pasgraad en persoonlikheidstipes wat deur Owens (2015:23) onderneem is, het aangetoon dat diegene wat die minste tevredenheid in hulle beroep ervaar, die persoonlikheidstipes blyk te wees wat aan die teenoorgestelde pool van die 'model'-persoonlikheidstipes lê. 'n Aantal studies wat deur Briggs-Myers et al. (2003:303) onderneem is, het ook aangetoon dat die persoonlikheidstipes wat die laagste in 'n gegewe beroep verteenwoordig word gewoonlik geneig is om minder tevredenheid met hulle beroep ervaar. Mense met hierdie persoonlikheidstipes toon ook'n groter intensie om 'n beroep te verlaat. In beide gevalle is deur hierdie navorsing onder predikante in die GKSA vasgestel dat die Flegmatiese persoonlikheidskombinasie die mees algemeen verteenwoordig word. Daar kan dus aanvaar word dat hierdie persoonlikheidstipe om hierdie rede oor die algemeen ook positiewe beroepservaring behoort te beleef. Aan die teenoorgestelde pool verteenwoordig die
Sanguiniese persoonlikheidstipe 'n moontlike risikogroep. Volgens hierdie teoretisering behoort die groepe oor die algemeen ook die laagste werkstevredenheid te ervaar.

Dit blyk egter dat daar vir die Sanguiniese persoonlikheidstipe ondersteuningsnetwerke in die bediening ontwikkel behoort te word. Die Sanguiniese groep benodig veral hulp om negatiewe emosies konstruktief te hanteer en te verwerk. In hierdie verband behoort daar spesifiek in die pastorale gesprek met die Sanguiniese predikant aandag geskenk te word aan eienskappe soos liggeraaktheid, wraaksug, selfbejammering, pessimisme, selfverkleinering, afgetrokkenheid en negatiwiteit. Volgens Spector (2012:221) mag hierdie negatiewe eienskappe die Sanguiniese predikant se belewenis van werkstevredenheid direk beïnvloed.

Daar moet dus in die pastorale gesprek - veral met die Sanguiniese predikant - gefokus word op die ontwikkeling van eienskappe wat hulle in hul dienswerk kan belemmer. By die Sanguiniese predikant moet veral aandag geskenk word aan impulsiwiteit, swak wilskrag en selfaanvaarding. Voorkeurgedrag en positiewe eienskappe soos getrouheid, empatie, kreatiwiteit, entoesiasme en goedhartigheid behoort verder ontwikkel te word, veral wanneer die spesifieke predikant hierdie eienskappe onderbenut. Dit is veral belangrik dat daar tydens die pastorale gesprek ondersoek ingestel moet word na elke persoonlikheidstipe se voorkeurgedrag, veral gedrag wat aanleiding tot interpersoonlike konflik of sielkundige spanning kan gee.

Persoonlikheidstipes verskaf waardevolle inligting wat uit interaksie met die werksomgewing voortvloei. Coetzee en Schreuder (2002:54) wys daarop dat verskillende werksomgewings verskillende belonings en geleenthede vir die onderskeie persoonlikheidstipes bied. Verskillende persoonlikheidstipes word ook deur verskillende werksomgewings gemotiveer en beleef dit wat interessant en bevredigend is op verskillende wyses. Deur middel van pastorale toerusting met behulp van persoonlikheidsontleding kan nuwe benaderings ontwikkel word waarbinne 'n bepaalde predikant in ' $n$ bepaalde werksomgewing meer effektief en lonend kan funksioneer. Die gevoel moet uiteindelik meer werksbevrediging wees.

\section{Die toepassing van die navorsing op 'n pastorale toerustingsmodel}

Volgens Coetzee en Schreuder (2002:59) het persoonlikheidstipes bepaalde implikasies vir 'n spesifieke rol of situasie waarin ' $n$ persoon goed funksioneer of pas. Dit is egter noodsaaklik om in gedagte te hou dat verskillende persoonlikheidstipes wel in 'n bepaald konteks goed kan funksioneer. Om hierdie rede besit alle persoonlikheidstipes komponente wat aan ontwikkeling onderhewig is. Met ontwikkeling (deur assessering en pastorale berading) kan individuele predikante gehelp word om by bepaalde situasies aan te pas deur bepaalde aspekte van hulle persoonlikheidstipe te benut of te ontwikkel. 
Die bewustheid wat uit persoonlikheidsontleding voortvloei, is ' $n$ nuutgevonde bewustheid van individuele voorkeure, asook sterk of swak punte in wisselwerking met die predikant en sy sosiale, lewens- en werksomgewing. In die konteks van die predikant bring dit ook vernuwende insig van hoe die Here unieke en uiteenlopende individue in sy diens gebruik. Hierdie vernuwende insig kan bydra tot geestelike en emosionele groei om die uitdagings van die hedendaagse bediening meer doeltreffend te kan hanteer en bestuur.

Kennis van individuele persoonlikheidstipes kan om hierdie rede 'n groot bydrae lewer om situasies en persoonlike aspekte te identifiseer waar individuele predikante moontlik spanning beleef. Ook kan dit individue help om by sekere situasies of beroepsrolle wat uit pas is of as stresvol beleef word, aan te pas. Dit is egter belangrik om daarop te wys dat, alhoewel die teenwoordigheid van persoonlikheidstipes soos hierbo aangetoon, ' $n$ merkwaardige rol by predikante se ervaring van hulle dienswerk speel, blyk persoonlike roeping steeds die bepalende faktor te wees waarom individue die roeping as predikant in die GKSA volg. Dit is om hierdie rede vir individuele predikante belangrik om kennis van hulle intrinsieke geneigdhede en voorkeure te dra en hoe dit hulle belewenis van hulle beroep mag beïnvloed. Uit die navorsing, ook soos dit uit hierdie empiriese studie blyk, roep God uiteenlopende persone tot sy diens. Elke predikant ervaar en benader sy dienswerk op 'n unieke wyse. Hierdie uniekheid skep die noodsaaklike rol wat persoonlikheid in die beroepservaring van predikante speel.

Die gegewens uit die empiriese ondersoek gee beduidende inligting oor hoe positief individuele predikante hulle dienswerk ervaar en hulle vatbaarheid vir die belewenis van sielkundige spanning. Mense is, volgens Nikolaou (2003:642), nie 'gyselaars' van hulle persoonlikheid nie, maar besit juis aktiewe persoonlikheidstipes wat hulle in staat stel om doelbewus of onbewustelik gedrag aan te pas. Veral in die kontemporêre wêreld moet almal oor die vermoë beskik om hulle persoonlike benaderings te kan aanpas by veranderende omstandighede of omgewings (Niemann 2020:5). Dit is in hierdie konteks wat 'n pastorale toeligtingsmodel konstruktiewe toeligting kan bied.

\section{Gevolgtrekking}

In die lig van die verspreiding van persoonlikheidstipes is risikogroepe vir diensverlating geïdentifiseer. In geheel beoordeel, is die verteenwoordiging van die persoonlikheidstipes onder predikante in die GKSA verspreid en word elk van die vier primêre persoonlikheidstipes tot 'n mindere of meerdere mate verteenwoordig. Die grootste persentasie van predikante sorteer binne die Flegmatiese persoonlikheidstipe. Die Sanguiniese persoonlikheidstipe is die laagste onder predikante verteenwoordig. Daar is dus vasgestel dat predikante ' $n$ algemene neiging na die onemosionele introverse persoonlikheidstipe toon.

Dit blyk dat daar'n verband tussen die soort werksaktiwiteite wat mense vervullend vind en die tipe omgewing wat hulle verkies, bestaan. Wanneer daar 'n dinamiese interaksie tussen die persoon en die omgewing bestaan, blyk dit beroepservaring positief te beïnvloed. Verskillende werksomgewings bied verskillende belonings en geleenthede vir die onderskeie persoonlikheidstipes. Daar is vasgestel dat verskillende werksomgewings deur die onderskeie persoonlikheidstipes as bevredigend beleef word. Diegene met bepaalde persoonlikheidstipes is aangetrokke tot sekere beroepe. Hierdie voorkeurberoepe verg eienskappe wat tot positiewe funksionering aanleiding gee. Om hierdie rede deel persone in dieselfde beroep soortgelyke persoonlikheidseienskappe. Omdat daar 'n geneigdheid tot die Flegmatiese persoonlikheidstipe bestaan wat GKSA predikante betref, blyk die rolvereistes van hierdie predikante ook in ooreenstemming te wees met die kenmerke van hierdie persoonlikheidstipe.

Persoonlikheidstipes wat 'n groter verteenwoordiging binne 'n gegewe beroep het, toon normaalweg ook 'n groter mate van werkstevredenheid omdat hierdie persoonlikheidstipes gewoonlik ook meer in ooreenstemming met hulle gekose beroep is. Daar kan dus aanvaar word dat hulle om hierdie rede oor die algemeen ook positiewe beroepservaring behoort te beleef. Die persoonlikheidstipes wat 'n lae verteenwoordiging binne 'n gegewe beroep het, loop 'n groter risiko vir die ervaring van sielkundige spanning. Persone met hierdie persoonlikheidstipes toon ook 'n groter intensie om 'n beroep te verlaat as die persoonlikheidstipes wat meer algemeen verteenwoordig word.

Hierdie navorsing bied aan predikante 'n konseptuele raamwerk van effektiewe gedrag en individuele verskille. Daar is ook vasgestel dat daar 'n verhouding tussen persoonlikheidstipes, rolvereistes en persoonlike ingesteldheid bestaan wat perspektief bied oor die positiewe funksionering van predikante in die GKSA. Hierdie navorsing lewer verder ook ' $n$ bydrae tot die aanpassing van inherente persoonlikheidsbehoeftesby die eksterne vereistes van dié roeping. Deur middel van persoonlikheidsontleding, pastorale berading en nuwe benaderings kan individuele ontwikkeling binne ' $n$ bepaalde werksomgewing meer effektief en bevredigend wees. Die uiteindelike gevolg moet die predikant se positiewe werkservaring wees.

Dit is veral belangrik dat daar tydens die pastorale gesprek ondersoek ingestel moet word na elke persoonlikheidstipe se voorkeurgedrag en inherente persoonlikheidsbehoeftes veral gedrag en behoeftes wat aanleiding tot interpersoonlike konflik of sielkundige spanningkan gee.

\section{Bydrae}

Hierdie artikel het 'n praktiese model beskikbaar gestel om moontlike redes vir diensverlating van predikante in die GKSA te verskaf. Daar is ook 'n raamwerk met die hulp van persoonlikheidsontleding verskaf om moontlike risikofaktore op intra-persoonlike vlak te identifiseer. Verder is daar 
bepaal dat persoonlikheidsteuring ' $\mathrm{n}$ rol in die pastoraat kan speel. Persoonlikheid dien die pastoraat daarin dat dit 'n werkbare middel kan wees vir die oplossing van intra- en ekstra-persoonlike spanning in die konteks van die predikant in die GKSA.

\section{Erkenning \\ Mededingende belange}

Die outeur verklaar dat hy geen finansiële of persoonlike verhouding(s) het wat hom in die skryf van die artikel onregmatig beïnvloed het nie.

\section{Outersbydrae}

G.J.N. was die enigste outeur betrokke by die skryf van die artikel.

\section{Befondsing}

Hierdie navorsing het geen spesifieke toekenning ontvang van enige befondsingsagentskap in die openbare, kommersiële of nie-winsgewende sektore nie.

\section{Data beskikbaarheid}

Die outeur bevestig dat die data wat die bevindings van hierdie studie ondersteun, beskikbaar is in die artikel.

\section{Vrywaring}

Die sienings en menings wat in hierdie artikel uitgedruk word, is dié van die outeur en weerspieël nie noodwendig die amptelike beleid of posisie van enige geaffilieerde verwantskap van die outeur nie.

\section{Literatuurverwysings}

Allen, R., 2010, The complete book of personality tests: Learn about and develop you personality quotient, Carlton Books, London.

Becvar, D.S. \& Becvar, R.J., 2009, Family therapy: A systemic integration, 7th edn., Pearson, Boston, MA.

Bennett, A. \& Bennett, L., 2005, The temperament God gave you: The classic key to knowing yourself, getting along with others, and growing closer to the Lord Sophia Institute, Manchester.

Berens, L.V. \& Nardi, D., 1999, The sixteen personality types: Descriptions for selfdiscovery, Telos Publications, CA.

Briggs-Myers, I., McCaulley, M.H., Quenk, N.L. \& Hammer, A.L., 2003, MBTI manual: $A$ guide to the development and use of the Myers-Briggs Type Indicator Instrument, 3rd edn., CPP, CA.

Burger, J.M., 2004, Personality, 6th edn., Wadsworth, Belmont, CA.

Burke, J., 2013, Mud and the masterpiece: Seeing yourself and others through the eyes of Jesus, Baker Books, MI.

Carter, P., 2007, IQ and personality tests: Assess your creativity, aptitude and intelligence, Kogan Page, London.

Cavanaugh, J.C. \& Blanchard-Fields, F., 2011, Adult development and aging, International Edition, 6th edn., Wadsworth, Belmont, CA.

Chess, S. \& Thomas, A., 1996, Temperament theory and practice, Brunner Mazel, New York, NY

Coetzee, M. \& Schreuder, A.M.G., 2002, 'The relationship between career pattern and personality types', SA Journal of Industrial Psychology 28(1), 53-59. https:// doi.org/10.4102/sajip.v28i1.41

Colman, A.M., 2009, Oxford dictionary of psychology, Oxford University Press, New York, NY.

Du Toit, L.B.H., 2005, Handleiding vir die Jung-persoonlikheidsvraelys (JPV). Katalogusnommer: 1879, Raad vir Geesteswetenskaplike Navorsing, Pretoria.
Erdogan, B. \& Bauer, T.N., 2005, 'Enhancing career benefits of employee proactive personality: The role of fit with jobs and organizations', Personnel Psychology 58(1), 859-891. https://doi.org/10.1111/j.1744-6570.2005.00772.x

Faulkner, B.R., 2001, Leaving - Why ministers leave the ministry. Advisory group on why Protestant Ministers leave the ministry, University of Washington, Washington, DC

Feist, J. \& Feist, G.J., 2009, Theories of personality, 7th edn., McGraw-Hill, New York,

Grobbelaar, K.G., 2007, 'Hulpverlening tot streshantering by predikante van die Gereformeerde Kerke in Suid-Afrika (GKSA): 'n Pastorale studie', PhD-proefskrif, Noordwes-Universiteit, Potchefstroom.

Heitink, G., 1984, Gids vir het pastoraat, Kok, Kampen.

Heller, D., Judge, T.A. \& Watson, D., 2002, 'The confounding role of personality and trait affectivity in the relationship between job and life satisfaction', Journal of Organizational Behaviour 23(7), 815-835. https://doi.org/10.1002/job.168

Hogan, R., 2014, EQ in the healthcare industry, Hogan Assessment Systems Inc.

Holland, J.L., 1996, 'Exploring careers with typology: What we have learned and some new directions', American Journal of Psychology 51(1), 397-406. https://doi. org/10.1037/0003-066X.51.4.397

Johns, G. \& Saks, A.M., 2005, Organizational behaviour: Understanding and managing life at work, 6th edn., Pearson, Toronto.

Joubert, P., 2005, Temperamentsvraelys, Noordwes-Universiteit, Potchefstroom.

Jung, C.G., 1971, Psychological types, Princeton University Press, Princeton.

Kristof-Brown, A.L., Zimmerman, R.D. \& Johnson, E.C., 2005, 'Consequences of individuals' fit at work: A meta-analysis of person-job, person-organization, person-group, and person-supervisor fit', Journal of Personnel Psychology 55(2), 281-342. https://doi.org/10.1111/j.1744-6570.2005.00672.x

Kummerow, J.M. \&Quenk, N.L., 2003, Understanding your BMTI step II results: A stepby-step guide to your unique expression of type, CPP, CA.

Larsen, R.J. \& Buss, D.M., 2010, Personality psychology: Domains of knowledge about human nature, McGraw-Hill, New York, NY.

Lounsbury, J.W., Steel, R.P., Gibson, L.W. \&Drost, A.W., 2008, Personality type and career satisfaction of human recourse professionals, eCareerFit.com, Inc., Atlanta, GA.

Louw, D. \& Louw, A., 2007, Die ontwikkeling van die kind en die adolessent, $\mathrm{ABC}$ Drukkers, Bloemfontein.

Louw, D.A. \& Edwards, D.J.A., 2003, Sielkunde: 'n Inleiding vir studente in Suid-Afrika, 2de uitgawe, Heinemann, Johannesburg.

Maartens, M., 2002, Moeilike mense, LAPA Uitgewers, Pretoria.

McAdams, D.P., 2009, The person: An introduction to the science of personality psychology, 5th edn., Wiley, Hoboken, NJ.

Meyer, W., Moore, C. \& Viljoen, H., 2003, Personology: From individual to ecosystem 3rd edn, Heinemann, Cape Town.

Mischel, W., Shoda, Y. \&Ayduk, O., 2008, Introduction to personality: Toward an integrated science of the person, John Wiley \& Sons, Hoboken, NJ.

Moerdyk, A., 2012, The principles and practice of psychological assessment, Van Schaik, Pretoria.

Niemann, G.J., 2010, 'Die persepsies en belewenis van uitbranding by nagraadse teologiese studente van die Gereformeerde Kerke in Suid-Afrika - 'n Pastorale studie', MTh-skripsie, Noordwes-Universiteit, Potchefstroom.

Niemann, G.J., 2020, 'What if I'm my own worst critic? Conversations in psychology', School of Psychology Newsletter, Arden University, Issue 4.

Nikolaou, I., 2003, 'Fitting the person to the organisation: Examining the personalityjob performance relationship from a new perspective', Journal of Managerial Psychology 18(7), 639-648. https://doi.org/10.1108/02683940310502368

Onoyase, D. \& Onoyase, A., 2009, 'The relationship between personality type and career choice of secondary school students in federal government colleges in Nigeria', Anthropologist 11(2), 109-115. https://doi.org/10.1080/09720073.2009 11891090

Oswald, R.M. \& Kroeger, O., 1999, Personality type and religious leadership, The Alban Institute Publications, Durham, NC.

Owens, M., 2015, Personality type \& career achievement: Does your type predict how far you will climb? A survey of career outcomes among the Briggs Myers' 16 personality types, Type Finder, San Francisco, CA.

Papalia, D.E., Wendkos Olds, S. \& Dukskin Feldman, R., 2008, A child's world: Infancy through adolescence, 11th edn., McGraw-Hill, New York, NY.

Rowell, J.L., 2010, 'Ministerial attrition: When clergy call it quits. The relationship of superintendents and pastors', paper presented at ANSR Conference, Olivet Nazarene University, Bourbonnais, Illinois, 25th March.

Sewell, S.M., 2008, Pastoring the temperament: A guide for pastoral counselling, Xlibris, Bloomington, IN.

Spector, P.E., 2012, Industrial and organizational psychology: Research and practice, Wiley, Danvers, MA. (International Student Version).

Stone, M.H., 2009, The anatomy of evil, Prometheus Books, New York, NY

Strelau, J., 1998, Temperament: A psychological perspective, Plenum Press, London.

Terre Blanche, M., Durrheim, K. \& Painter, D., 2010, Research in practice: Applied methods for the social sciences, University of Cape Town Press, Cape Town. 